\title{
Development of Kinect- Based Science Learning Media to Support Improvement of Cognitive Learning Outcomes
}

\author{
Fajar Fitri ${ }^{*}$, Laifa Rahmawati \\ 1,2 Physics Education Study Program, Universitas Ahmad Dahlan \\ Jln. Kapas No.9, Umbulharjo, Yogyakarta, 55166 \\ Corresponding Author. Email: fajarfitri@gmail.com
}

\section{Keywords: \\ learning media, Kinect-based, learning outcomes.}

\begin{abstract}
The purpose of this study is to describe the grant of science based learning media Kinect to support the improvement of students' learning outcomes from cognitive aspect. This research is an educational development research which is adapted from the development model according to Borg \& Gall. The research was conducted in four main stages, that are (1) needs analysis, (2) instructional design, (3) media development, (4) validation. Instruments used in this research are assessment sheets by validator, student response questionnaires, pretests, and post test. After being validated, the media was tested to ten students, so that the results obtained of student responses and the effectiveness of improving students' cognitive learning outcomes. The result of the development is Kinect-based science learning media. From the results of research and development stage as well as experiments that have been done can be concluded that the product can improved student learning outcomes in cognitive aspect.
\end{abstract}

C2018 JSER. Yogyakarta State University.

\section{INTRODUCTION}

Education should be able to answer the challenge in the era of globalization. Society in 2020 must be able to compete globally with other nations. This should be addressed seriously so that later graduates are able to compete with the international community. Variety of ability must necessarily be given in teaching, especially the ability to dig information from various sources. The ability to extract information includes the ability to observe, ask, gather information, and associate or analyze. These capability need to be developed in students through the course despite knowledge is a main factor. Lectures should be able to provide students the knowledge and ability to extract information. Selection of instructional media, in addition to methods and learning models in the lectures, has an effect of improving student learning outcomes.

In a learning naturally required a manual in the form of a learning device (Anggarniastiti, dkk., 2017). Lecturer as facilitators in the lectures are required to skillfully develop appropriate learning media in conveying the course materials so that students are able to master the material and also have various capabilities of extracting information.

Mechanics is one of the subjects in the study program of Physical Educationat Ahmad Dahlan University. The material of mechanics is one of the difficult materials for the students. There are problems faced by students at the time of study mechanical materials. The average of the students' learning outcomes when studying the mechanics material only on 4.5 of the total points 10.

There are several things that factor into the causes of low acquisition value of student on mechanics material. Students learn the material of mechanics was limited to formulas when the material of mechanics requires understanding rather than just memorization. Students do not understand the basic concepts of mechanics so as 
to be to understand the mechanics the students continue to find difficulties. Students are not able to understand the application and evidence of

Learning media needed bystudents to help their conceptual understanding in mechanical materials. Learning media that appeal the college students also support the emergence of interest and willingness to learn the material of mechanics.

Kinect is one of the learning media that can be used as an interactive media."Kinect sensor is used as an input to the virtual reality environment, which in turn is monitored by the monitoring software package. Kinect is a sensor that follows the movement of the limbs. "Kinect is a motion sensing input device used in the Xbox 360 console consisting of four major components: an RGB camera, 3D depth sensors. A multi-array microphone, and built-in processing cores (Kinect for Windows 2014). Users can employ gestures or voice commands to operate the Xbox system interface without having to use a handheld remote controller."[4]"Kinect recognizes and tracks human skeleton. It identifies the coordinates of the 25 joints of the human body, establishes the human skeleton structure, and combines the depth information to represent the human skeleton structure in three-dimensional space.

Kinect can be used in learning to make students feel happy. "Kinect motion sensing gamebased learning environment offers a new sensory experience for the students to fully mobilize all senses to get involved in learning and interactions. As a learning tool, Kinect has the affordances to create enjoyable, interesting interactions types, to improve students motivation, and to promote learning by its multimedia and multi-sensory capacity.. The development of Kinect-based learning media on mechanical materials is expected to support the improvement of student learning outcomes.

\section{METHOD}

This research is a research and development (research and development) which has produced a product orientation. Products developed in this research is a learning media and mechanical material. Learning media developed aimed to improve student learning outcomes. Development procedure in this study refers to the stage of development models adapted from the Borg \& Gall model and the model established by the researcher. The study was conducted on four main stages, namely (1) needs analysis, (2) instructional design, (3) media development, and (4) validation. The instrument used in this research is the assessment sheets by the validator.[8] mechanics' concept in everyday life. This indicates that mechanics is a complex and abstract material.

\section{RESULTS}

The main product of this research is Kinectbased science learning media. Learning media which is developed based on Macromedia Flash Professional 8 was also developed to enrich the Kinect-based learning media. Focused on mechanics material, the media is comprised of four main menu; impulse, momentum, collision, and animation. Research and development process has been completed to include four stages, they are (1) the analysis of needs, (2) instructional design, (3) the development media, (4) validation, revision, and the early product trials. There are two types of data gained in this research, data of product validation and data of student pretest postest.

\section{Product Validation}

Media product validation is the process of validator assessment to the feasibility aspect of the product. Validator in this study consisted of an expert lecturer and four students. Validators provides an assessment of the media from the three aspects, they are learning, material, and media aspect. The assessment instrument on the learning aspect consists of 12 assessment items, the material aspect consists of 6 assessment items, and the media aspect consists of 14 assessment items. Assessment score given by the validator then converted using a five-point scale with a category A (excellent), B (good), C (enough), D (poor), and $\mathrm{E}$ (very less ). Based on the citation on a scale of five, the maximum score is worth 5 and the minimum score is 1 given validator on each item assessment.

The benchmarks in this research that if the total score which converted into a 5-point scale of assessment given by the validator indicates the value " $\mathrm{C}$ " to category "Enough" then learning media product development has been deemed unfit for use. Tabulation of the total score that can be converted into a 5-point scale is presented in Table 1. The result of the conversion of the total mean score on each of the aspects that is presented in Tables 2, 3, and 4. Based on the result of conversion, each aspect of quality product assessment can be analyzed as follows .

\section{Aspects of Learning}

Assessment aspects oflearning by an expert lecturer belonging to the value of $\mathrm{A}$ by the category of "very good" and four students are in 
the category of B to a category of "good". In Table 1 , shows the result data validator on aspects of learning.

The Material Aspects
The assessment material aspects by an expert lecturer is included in category B value with the value of "good" and four students are in the category B with a value of "good". In Table 2, is shown the result data validator vote on aspects of learning.

Table 1. Data Validator Aspects Assessment of Learning

\begin{tabular}{llcc}
\hline \multicolumn{1}{c}{ Sub-aspect of learning } & \multicolumn{2}{c}{ Average sub-aspect score by validator } \\
\cline { 3 - 4 } & & Expert lecturer & Student \\
\hline A & clarity of learning outcomes & 4 & 3.75 \\
B $\quad$ ability to motivate & 5 & 3.25 \\
C & organizing materials and procedures & 4.2 & 4.15 \\
D & opportunities for student participation & 4.5 & 4.25 \\
Total aspect scores & 52 & 47 \\
value / category & Very good/A & Good/B \\
\hline
\end{tabular}

Table 2. Data Validator Aspects Assessment Materials

\begin{tabular}{llcc}
\hline \multirow{2}{*}{ Sub-aspect of material } & \multicolumn{2}{c}{ Average sub-aspect score by validator } \\
\cline { 2 - 4 } & & Expert lecturer & Student \\
\hline A & material completeness & 4.5 & 4 \\
B & material accuracy & 5 & 4.25 \\
C & material upgrades & 5 & 4.75 \\
D & materials follow the scientific system & 5 & 3.75 \\
E & use of notation, symbols, and units & $\mathbf{2 4}$ & 3.75 \\
Total aspect scores & Good/B & Good/B \\
value / category & &
\end{tabular}

Table 3. Data of Validator Rating Result on Aspect of Media

\begin{tabular}{llcc}
\hline \multirow{2}{*}{ Sub-aspect of media } & \multicolumn{2}{c}{ Average sub-aspect score by validator } \\
\cline { 3 - 4 } & & Expert lecturer & Student \\
\hline A & legibility & 4.5 & 3.75 \\
B & ease of use & 5 & 4 \\
C & screen design view & 4.5 & 4 \\
D & student responses handling & 3.5 & 3.75 \\
E & program management & 4.5 & 4.25 \\
Total aspect scores & $\mathbf{6 3}$ & $\mathbf{5 6}$ \\
value / category & Very Good/A & Good/B & \\
\hline
\end{tabular}

\section{Media Aspect}

Media aspects assessment done by an lecturer belonging to the value of A by the category of "very good" and by four students to the value of B by the category of "good". In Table 3 are shown the data validator assessment results on the media aspect. Based on the evaluation of media on the learning aspect, materials, and media by an expert lectures and four students who obtained excellent or good value, then it can be concluded that the learning media development can be used in the learning.

\section{Limited Test}

Limited test conducted to ten $3^{\text {rd }}$ grade students of Physics Education Study Program UAD. In this limited test, students are asked to finish pretest and posttest examination. The mean value of the pretest students is 5.2. This value indicates that the average grade value in mechanical material was not met the minimum value stipulated mastery course lectures of 7.5. After pretest the next step is learning use Kinect-based science learning media that has been developed. Then the students finish the posttest. The posttest results showed that the average value of 8.7 .

\section{CONCLUSION}


Fajar Fitri \& Laifa Rahmawati / JSER 2018, 2(1), 12

It can be stated that by using the Kinectbased science learning media, student learning outcomes in cognitive aspect can be improved. Students also meet mastery courses value for the average value more than 7.5.

\section{REFERENCES}

Bloom, B. S. (1976). Human Characteristics and School Learning. New York: McGraw Hill.

Borg, W.R., Gall, M.D., \& Gall, JP. (2007). Educational Research: An Introduction. Boston: Allyn \& Bacon.

Heinich, Robert et al. (1996) Instructional Media \& Technologies for Learning. Columbus: Merrill Prentice Hall.

Hui Qu. (2017). Application of Kinect Technology in Blind Aerobics Learning. International Journal of Emerging Technologies in Learning Vol 12, No 12.

Hui Yu Yang, Hao Zhan, Wei Xu, Ping Jian Zhang, Liang Ming Xu. (2014). The Application of Kinect Motion Sensing Technology in GameOriented Study. International Journal of Emerging Technologies in Learning. Vol 9, No 2 .

Hui-Mei Justina Hsu. (2011). The Potential of Kinect in Education. International Journal of
Information and Educational Technology, Vol 1. No. 5 .

Joao Couto Soares, Agata Vieira, Octavian Postolache, Joaquim Gabriel. (2013). Development of a Kinect Rehabilitation System. International Journal of Online Engineering Vol 9.

Reigeluth, Charles M \&Carr-Chellman, Alison A. (2009). Instructional-Design Theories and Models. New York: Routledge.

Sagirani, T., Ferdiana, R., and Kumara, A. (2013). The framework of learning media development for the children with special need. Innovation and Technology in Education (MITE), 2013 IEEE International Conference in MOOC, pp. 180-184.

Tiffani Anggarniastiti, Dadan Rosana, Wita Setianingsih. (2017). The development of science learning device based on science edutainment to improve student's learning motivation and cognitive learning achievement. Journal of Science Education Research Vol 1, No 1.

Yi-Hsing Chang, Jhen-Hao Hwang, Rong-Jyue Fang, You-Te Lu. A Kinect and game Based Interactive Learning System. EURASIA Journal of Mathematics Science and Technology Education. $2017 \quad 13$ (8). 